\title{
INTEREST RATE PASS-THROUGH IN TURKEY AND IMPACT OF GLOBAL FINANCIAL CRISIS: ASYMMETRIC THRESHOLD COINTEGRATION ANALYSIS
}

\author{
Ebru Yüksel $^{1}$, Kıvılcım Metin Özcan² \\ ${ }^{1}$ Department of Industrial Engineering, Hacettepe University, 06810 Beytepe Ankara, Turkey \\ ${ }^{2}$ Department of Economics, Necmettin Erbakan University, Karatay Konya, Turkey \\ E-mails: ${ }^{1}$ eyuksel@hacettepe.edu.tr (correspondingauthor); ${ }^{2}$ kivilcim.metin@gmail.com
}

Received 19 August 2011; accepted 27 February 2012

\begin{abstract}
This paper aims to investigate the interest rate pass-through of monetary policy rate to banking retail rates in Turkey by employing the asymmetric threshold autoregressive (TAR) and momentum threshold autoegressive (MTAR) procedures introduced by Enders and Siklos (2001). Over the period December 2001 to April 2011, the empirical results of asymmetric threshold cointegration analysis suggest that there exist significant and complete pass-through between policy rate and loan rates. Positive and negative departures from the equilibrium converge to long run path almost at the same speed. Pace of convergence is about two to three months for all loan rates. Policy rate has significant short run impact on loan rates. Our analysis revealed that there is no significant relationship between policy rate and bank deposit rates due to sluggish adjustment of deposit rates. Lastly, the speed and behavior of interest rate pass-through between policy rate and loan rates did not change when we encounter the effect of 2008 financial crisis. Having a banking sector dominated financial system in Turkey, the results suggest that banks adjust loan rates faster than deposit rates. This indicates that Central Bank can affect the consumption behavior of people, in other words aggregate demand through loan rates.
\end{abstract}

Keywords: asymmetric threshold cointegration, banking retail rate, interest rate passthrough, loan rate, monetary policy, monetary transmission mechanism.

Reference to this paper should be made as follows: Yüksel, E.; Özcan, K. M. 2013. Interest rate pass-through in Turkey and impact of global financial crisis: asymmetric threshold cointegration analysis, Journal of Business Economics and Management 14(1): 98-113.

JEL Classification: C22, E43, E52.

\section{Introduction}

The outbreak of global economic and financial crisis starting in 2008 has attracted a lot of studies, which emphasize the importance of the monetary transmission mechanism. To evaluate the performance of monetary policy, interest rate transmission channel turns out to be essential for conducting interest rate pass through analysis. Interest rate passthrough is described as the degree and speed of adjustment in banking retail interest rates to changes in monetary policy rates. High interest rate pass-through defines the close link between monetary policy rate and retail banking rate. Since individuals and 
financial agents shape their investment, saving and consumption decisions with respect to deposit and lending rates (banking retail rates), it is important for central banks to influence the banking retail rates through monetary policy actions. For this, central banks use monetary policy rates to affect banking retail rates. Efficiency of this mechanism is important especially for countries using interest rate channel as the monetary policy transmission mechanism. Complete pass-through means that changes in policy rates are totally transferred to banking retail rates so monetary policy decisions can be implemented successfully by central banks. Such a pass-through mechanism indicates the effectiveness of interest rate channel in establishing price stability and strong banking system.

Especially for inflation targeting countries, the relationship and adjustment degree between policy rate and banking retail rates are highly examined under the concept of interest rate pass-through (see e.g. Kwapil, Scharler 2006; De Bondt 2005; Sander, Kleimeier 2004). Turkey implemented implicit inflation targeting regime between 2002 and 2005 (Kara 2006). After that, explicit inflation targeting regime is accepted as main monetary policy stance. Thus, there are two studies focusing on interest rate pass-through in Turkey after the inflation targeting regime conducted. Aydin (2007) previously analyzed the interest rate pass-through in Turkey using linear cointegration. Aydin (2007) uses data for individual banks operating in Turkish banking system and classifies loan types to include corporate, housing, cash and automobile loans. The data set includes all public, private, foreign, investment and development banks. Thus, Aydin (2007) explores cointegration relationships in panel data and reveals the sources of heterogeneity in price setting behavior of banks in different types of loans. The empirical results revealed that monetary policy decisions are transmitted to loans market within a quarter. Housing loans are the most responsive rates to changes in the policy rate whereas; cash and vehicle rates are less responsive. Commercial loans were found to be adjusting incompletely.

Ozdemir (2009) also investigated pass-through mechanism from money market to retail rates between 2001 and 2006 in Turkey using symmetric and asymmetric error correction method. The estimation results indicated that retail rates adjust completely in the long run however, in the short run loan rate is flexible compared to deposit rate.

Within this perspective, the aim of this study is to examine interest rate pass-through mechanism in Turkey using asymmetric threshold cointegration method to capture the asymmetric behavior (if exists) of interest rate channel during the period December 2001 to April 2011. The superiority of this method with respect to traditional linear cointegration method is that asymmetric cointegration method takes into account asymmetric adjustment process among the interest rates, and nonlinearity in the pass-through mechanism due to asymmetric information or market structure (Wang, Lee 2009). Thus, when we analyze the interest rate pass-through mechanism in Turkey, we choose to employ asymmetric cointegration method following Enders and Siklos (2001) to observe (if there exists) asymmetric long run relationship between the monetary policy rate and banking retail rates. Our study differs from two previous studies, Aydin (2007) and Ozdemir (2009). We adopt asymmetric cointegration methodology while Aydin 
(2007) applied linear cointegration. The difference of our study from Ozdemir (2009) is twofold. First, we differentiate the data set so that instead of one aggregate loan rate we employed disaggregated retail rates. Second, our data covers longer time period starting from December 2001 to April 2011, which also enables us to analyze the global financial crisis period.

In our study, we employed cash, vehicle, housing and commercial loan rates as well as monthly weighted average of 1-month, 3-month, 6-month and 12-month deposit rates as banking retail rates and interbank overnight borrowing interest rate as the policy rate for the period December 2001 to April 2011. The long run relationship between banking retail rates and the policy rate is investigated using threshold autoregressive (TAR) and momentum threshold autoregressive (MTAR) methods. In order to analyze the impact of 2008 financial crisis, we used dummy variables for the period October 2008 to September 2009 during which Turkey has experienced negative growth rates.

The organization of the paper is as follows: Section 2 gives literature review. Section 3 presents brief information about Turkish banking system. Section 4 describes the data and explains the methodology used. The estimation results are stated in Section 5. Finally, Section 6 concludes the study.

\section{Literature review}

It is important to assess nature and speed of adjustment of retail banking interest rates to changes in policy rates for conducting an effective monetary policy. Thus, interest rate pass-through attracted great attention. For instance, De Bondt (2005) examined the interest rate pass-through in the euro zone by employing vector error-correction and vector autoregressive model. It was suggested that the pass-through is complete up to 3 months but incomplete for rates with longer maturities. After the introduction of euro, pass-through became faster. Andion et al. (2010) carried out a cointegration analysis among nominal and spread mortgage rates of member countries of European Union (EU) to search for the degree of integration among EU money markets. The estimation results indicated that there are no clear long term relationships between EU countries' mortgage series in 1995-2008 periods.

There are some studies focusing on interest rate pass-through mechanism in individual European countries. For example, Egert et al. (2007) found low and decreasing interest rate pass-through from policy rate to retail rates five Central and Eastern European countries - the Czech Republic, Hungary, Poland, Slovakia and Slovenia. However, the cointegration and error correction analysis revealed that there are still higher passthrough between policy rate and some corporate lending rates. Bruna (2008) investigated the effect of market interest rates on lending and deposit interest rate in Czech Republic alone during inflation stabilization period 1999-2006. The results of cointegration analysis suggested that lending and deposit rates react differently to changes in market interest rates both in long run and in short run. Changes in the banking sector influenced the adjustment mechanism among the market, deposit and lending interest rates.

Similarly, Chionis and Leon (2006) analyzed the properties of propogation mechanism from policy interest rate to lending and deposit interest rates in Greece before and after 
the access to EU. Using bivariate cointegration and error correction method, the study concluded that lending and deposit rate react more to policy rate after entering the EU however, the interest rate pass-through is still incomplete.

The interest rate pass-through process in Argentina is analyzed by Humala (2005) with employing Markov switching vector autoregression models. It was shown that financial crises change the adjustment level of short term lending rates to changes in interbank rate.

Recent literature showed that most of the macroeconomic variables such as inflation, national income, unemployment, interest rate display asymmetric adjustment to their long run equilibrium level (see e.g. Wang, Lee 2009; Sander, Kleimeier 2004; Enders, Siklos 2001). On the other hand, Haug and Siklos (2006) showed that the nonlinear models are superior to linear models in explaining the relationship between short term and long term interest rates. By using several developed country data and applying exponential smooth transition autoregression, they showed that especially during the periods of policy changes, nonlinear models are better in describing the behavior of short term interest rates. Therefore, there are various studies analyzing either symmetric or asymmetric adjustment properties of interest rate pass-through in different countries.

For instance, Sander and Kleimeier (2004) made such an analysis for the euro area using asymmetric cointegration method. After specifying structural breaks, it was shown that there is divergence in the pass-through mechanism of member nations although pass-through improved in deposit market due to increased competition in post-break periods. Later, Kleimeier and Sander (2006) studied interest rate pass-through in the European Union by explicitly describing expected and unexpected monetary shocks in their analysis. Their model was found to be successful in describing the behavior of loan interest rates even under asymmetric adjustment. However, for the deposit rates a slower pass-through was observed.

Hofmann and Mizen (2004) depicted the nature of interest rate pass-through in the UK. By allowing asymmetric and nonlinear adjustment processes, it was shown that the gap between the policy rate and the retail banking rates is the driving force of the interest rate pass-through so that when this gap is high the adjustment pace is rapid and when this gap is small the adjustment speed is slow. Later, Fuertes and Heffernan (2009) attracted attention to variations in the adjustment processes of financial firms' interest rates to changes in policy rate in the UK. Therefore, it was suggested that different retail rates set by financial firms may decrease the efficiency of monetary policy since consumers face distinct interest rates. However, the estimation results are parallel to the forecasts that there is a long run relationship between policy rate and retail rates.

Panagopoulos et al. (2010) explored pass-through from central bank/money market rates to deposit and lending rates in the U.S., Canada, the UK and Eurozone. The cointegration analysis allowing also asymmetric adjustment indicated that the UK and U.S. have positive long run interest rate pass-through while Canada and Eurozone have negative long run pass-through. 
Gambacorta and Iannotti (2007) explored the asymmetric properties of interest rate pass-through between policy rate and bank interest rates in Italy during 1985-2002. The estimation results of asymmetric error correction model showed that after 1993 degree of adjustment increased, adjustment is asymmetric only in the short run, loan rates are adjusted faster than deposit rates during monetary easing periods and this asymmetry has disappeared since 1990.

Payne (2006) examined the long run relationship between the federal funds rate and the 30 -year mortgage rate in the U.S. using momentum threshold autoregressive (MTAR) method following Enders and Siklos (2001). It was documented that there is symmetric incomplete pass-through between the interest rates in the long run. However, Cook (2008) used Bardsen transformation to investigate the properties of interest rate passthrough between federal funds rate and the mortgage rate in the U.S. Contrary to Payne (2006), Cook (2008) discovered complete pass-through.

Wang and Lee (2009) used the asymmetric threshold cointegration method following Enders and Siklos (2001) and the EC-EGARCH $(1,1)$-M model to analyze pass-through mechanism between the money market rate and the retail interest rate in the U.S. and nine Asian countries. The complete pass-through was found only for the U.S. deposit rate, supporting the work of Cook (2008). Asymmetric pass-through was seen in the deposit interest rate in five Asian countries and in the lending rate in three Asian countries. The symmetric cointegration relation was found to be existing in two Asian countries. Wang and Thi (2010) used asymmetric threshold cointegration test to analyze interest rate pass-through in Taiwan and Hong Kong. It was reported that there exist asymmetric and incomplete interest rate pass-through in both countries.

Lastly, Tai et al. (2012) examined the differences in the interest rate transmission mechanism of six Asian countries, which are Hong Kong, Indonesia, Korea, Malaysia, Philippines, Singapore and Thailand, using seemingly unrelated regression equations. They concluded that transmission from money market rate to deposit and lending rate is sluggish signaling inefficiency in transmission mechanism of the mentioned countries.

\section{Brief information on the Turkish banking system}

In 1999, an exchange rate based stabilization programme with International Monetary Fund (IMF) was announced to manage inflation expectations and decrease borrowing cost of Treasury. However, remarkable credit growth together with foreign exchange risk due to lack of commitment to structural reforms and delays in privatization programme of public banks led to liquidity crisis in 2000-2001 in Turkey. This was the end of 1999 stabilization programme. Devaluation costed more than $4 \%$ of gross national product, more than 10 banks went bankrupt and overnight interest rate increased beyond $15000 \%$ (Gormez 2008).

After the 2001 crisis, together with inflation targeting regime, re-structuring of public banks and re-capitalization of banks took place in a new stabilization programme (Gormez 2008). Implicit inflation targeting was implemented between 2002 and 2005, 
after which explicit inflation targeting was realized (Kara 2006). Owing to firm macroeconomic policies, the banking sector experienced a credit growth although currency risk was a threat due to floating exchange rate regime. However, the Central Bank of the Republic of Turkey was able to manage capital flows through market operations. As a result, banks in Turkey started to adapt themselves to low inflation business conditions together with new financial instruments (Gormez 2008; Ozdemir 2009).

Banks in Turkey become more powerful after recovering from 2001 crisis and growth in banking sector was observed. Financial Stability Report of 2007 prepared by the Central Bank of the Republic of Turkey stated that approximately $87 \%$ of Turkish financial system was composed of banks. According to statistics distributed by the Banks Association of Turkey, there are 31 deposit banks, 13 development and investment banks and 4 participation banks operating in Turkey as of December 2011. Of 31 deposit banks, 3 are state-owned, 11 are privately-owned, 16 are foreign banks and 1 is under the Deposit Insurance Fund. The total number of branches belonging to deposit banks and development and investment banks is 9834 . Total number of employees working in all deposit banks and development and investment banks is 181443 as of December 2011 (The Banks Association of Turkey Statistical Reports 2012). The Turkish banking sector has TL 1212374 million assets, TL 675575 million loans, TL 287212 million securities, TL 2109 million profit at the end of 2011 (Banking Regulation and Supervision Agency Press Release 2012).

\section{Data and methodology}

\subsection{Data}

To examine the interest rate pass-through mechanism in Turkey, we employed cash, vehicle, housing and commercial loan rates as retail rates and interbank overnight borrowing interest rate as the policy rate ${ }^{1}$. All data series are taken from Electronic Data Delivery System of Central Bank of the Republic of Turkey. Our data set consists of the period from December 2001 to April 2011.

As it is seen in Figure 1, although retail rates and policy rate seem to have a general decreasing trend in common, some discrepancies are observed during 2002, in the beginning of 2003, in the beginning of 2004, in the middle of 2006, during the second half of 2006 and in the beginning of 2009.

\subsection{Asymmetric cointegration and error correction (EC)}

In order to examine dynamic adjustment properties of retail banking rates to policy rate, we follow the threshold autoregressive (TAR) and momentum threshold autoegressive (MTAR) procedures introduced by Enders and Siklos (2001), to see whether there exists

\footnotetext{
${ }^{1}$ At the beginning of this study, we also included monthly weighted average of 1-month, 3-month, 6-month and 12-month deposit rates in our analysis. However, it is observed that due to sluggish adjustment of bank deposit rates (Agenor, Alper 2009) we could not find any significant cointegration relationship with the policy rate, contrary to Ozdemir (2009). We did not report the results to save the space. But they may be requested from the authors.
} 


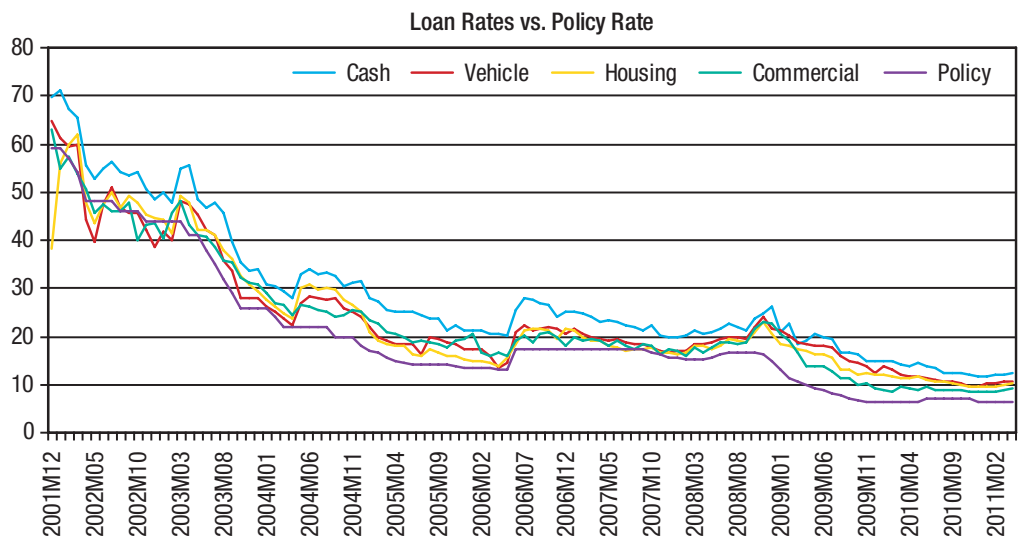

Fig. 1. Loan rates and policy rate in Turkey during 2001M12-2011M04

asymmetric long run relationship between the stated interest rates. The long run relationship between the banking retail rate and the policy rate is estimated by

$$
b_{t}=\mu_{0}+\mu_{1} p_{t}+e_{t},
$$

where $b$ is retail banking rate and $p$ is the policy rate. The degree of interest rate passthrough is measured by the coefficient $\mu_{1}$. Empirical studies revealed that speed of interest rate pass-through is slow in the short run. Similarly, various studies carried out for different countries imply that there is not a complete interest rate pass-through in the long run and the transmission speed is slow. There are different studies indicating that degree and speed of interest rate pass-through mostly depend on the type of interest rates used and the nature of the monetary system of the country under consideration.

Under perfect competition this coefficient is expected to be equal to 1 however, there are some factors/conditions that violate this equality and lead to interest rate stickiness and incomplete pass-through. For instance, depth of financial markets and switching costs affect the level of $\mu_{1}$ and cause it being less than 1 or cost of asymmetric information, adverse selection and moral hazard bring about a coefficient greater than 1 . All of these factors result in incomplete/over pass-through, which highly affects the effectiveness of monetary policy (Wang, Lee 2009).

To investigate the degree of adjustment including the asymmetric behavior specification between the banking retail rate and policy rate, we used the TAR model of Enders and Siklos (2001) as follows:

$$
\Delta e_{t}=I_{t} \rho_{1} e_{t-1}+\left(1-I_{t}\right) \rho_{2} e_{t-1}+\varepsilon_{t},
$$

where $e$ is the residual series of pass-through relationship, $\varepsilon$ is a zero-mean, constantvariance, iid random variable. $I$ is an indicator function specified as

$$
I_{t}= \begin{cases}1 & \text { if } e_{t-1} \geq \tau \\ 0 & \text { if } e_{t-1}<\tau,\end{cases}
$$

where $\tau$ is the threshold value, which is naturally set to zero in many economic applica- 
tions. This way, the adjustment degree will be $\rho_{1} e_{t-1}$ if there is positive deviation from the long run equilibrium level and $\rho_{2} e_{t-1}$ if there is negative deviation from the long run equilibrium (Enders, Siklos 2001). Then, in this TAR model, null hypothesis of no cointegration can be tested by $\rho_{1}=\rho_{2}=0$ and null hypothesis of symmetric adjustment can be tested by $\rho_{1}=\rho_{2}$.

In equation (3), replacing the level of previous period's residual $\left(e_{t-1}\right)$ with the change in the level of previous period's residual $\left(\Delta e_{t-1}\right)$ produces the momentum threshold autoregressive (M-TAR) model with the following indicator function:

$$
M_{t}= \begin{cases}1 & \text { if } \Delta e_{t-1} \geq \tau \\ 0 & \text { if } \Delta e_{t-1}<\tau\end{cases}
$$

TAR model is convenient to examine persistency of positive and negative departures of the series from their long run equilibrium. The asymmetric behavior in trough/peak movements of the series are detected by TAR model. On the other hand, M-TAR model is rather used to capture asymmetric sharp contractionary and/or expansionary movements of the series when they diverge from their long run equilibrium.

The EC representation for TAR model is given as

$$
\Delta b_{t}=\rho_{1} I_{t} e_{t-1}+\rho_{2}\left(1-I_{t}\right) e_{t-1}+\rho_{3} \Delta b_{t-1}+\rho_{4} \Delta p_{t-1}+\varepsilon_{t},
$$

where $b$ is retail banking rate, $p$ is the policy rate, $e$ is the residual series of pass-through relationship, $\varepsilon$ is a zero-mean, constant-variance, iid random variable and $I$ is the indicator function defined in equation (3).

Similarly, the EC equation of MTAR model is stated as

$$
\Delta b_{t}=\rho_{1} M_{t} e_{t-1}+\rho_{2}\left(1-M_{t}\right) e_{t-1}+\rho_{3} \Delta b_{t-1}+\rho_{4} \Delta p_{t-1}+\varepsilon_{t},
$$

where the only difference from the EC representation of TAR model is the indicator function $M$. Long term effect of policy rate on retail banking rates is observed through the coefficient of error correction term $e$, and the significance of these parameters can be tested by $\rho_{1}=\rho_{2}=0$ while symmetric adjustment properties can be examined by $\rho_{1}=\rho_{2}$. Short term relationship between the retail banking rate, its lag and the policy rate can be quantified by the coefficients $\rho_{3}$ and $\rho_{4}$, respectively ${ }^{2}$.

\section{Estimation results}

\subsection{Unit root test}

Before starting our analysis, unit root test is done to check whether the series are stationary or not. The results of the Augmented Dickey Fuller (ADF) test (see Dickey, Fuller 1979; Dickey, Fuller 1981; Said, Dickey 1984) are shown in Table 1.

\footnotetext{
${ }^{2}$ In TAR models, the adjustment parameters differ depending on the position of the so-called indicator variable. Nonlinearities enter only in the ECM equation, where it is assumed that nonlinearities influence only the speed of adjustment towards the long run equilibrium. The indicator variables can take various specifications, including the size asymmetry, sign asymmetry and volatility asymmetry. However, this paper only considers sign asymmetry and ignores size and volatility asymmetries.
} 
Table 1. ADF test results for all series

\begin{tabular}{lccccc}
\hline & \multicolumn{3}{c}{ ADF Test Statistic } & & \multicolumn{2}{c}{ ADF Test Statistic } \\
\hline Level & Lag & Trend and Intercept & First difference & Lag & Trend and Intercept \\
\hline Cash & 0 & -3.01 & Cash & 0 & $-10.15^{*}(p$-value 0.00$)$ \\
\hline Vehicle & 11 & -2.24 & Vehicle & 10 & $-4.89^{*}(p$-value 0.00$)$ \\
\hline Housing & 11 & -1.82 & Housing & 10 & $-4.59^{*}(p$-value 0.00$)$ \\
\hline Commercial & 4 & -2.51 & Commercial & 3 & $-5.11^{*}(p$-value 0.00$)$ \\
\hline Policy & 1 & -3.15 & Policy & 1 & $-5.62^{*}(p$-value 0.00$)$ \\
\hline
\end{tabular}

Note: * denotes the rejection of null hypothesis at $1 \%$ siginificance level. Lag lengths are chosen according to Akaike Information Criterion (AIC). Critical values are from McKinnon (1996).

According to Table 1, the null hypothesis of level series have unit roots cannot be rejected based on McKinnon (1996) $p$-values. However, after taking the first differences, the ADF unit root test shows that the series are stationary at $1 \%$ significance level so that all series are integrated of order 1, I(1).

In addition to ADF test, Phillips-Perron unit root test due to Phillips and Perron (1988) and Kwiatkowski, Phillips, Schmidt and Shin (KPSS) test due to Kwiatkowski et al. (1992) are applied. Results of Phillips-Perron test and KPSS test are given in Table 2 and Table 3, respectively.

Table 2. Phillips-Perron unit root test results for all series

\begin{tabular}{lccccc}
\hline & Phillips-Perron Test Statistic & & \multicolumn{2}{c}{ Phillips-Perron Test Statistic } \\
\hline \multicolumn{1}{c}{ Level } & Bandwidth & $\begin{array}{c}\text { Trend } \\
\text { and Intercept }\end{array}$ & $\begin{array}{c}\text { First } \\
\text { difference }\end{array}$ & Bandwidth & Trend and Intercept \\
\hline Cash & 5 & -3.01 & Cash & 3 & $-10.14^{*}(p$-value 0.00) \\
\hline Vehicle & 1 & -3.55 & Vehicle & 4 & $-9.55^{*}(p$-value 0.00) \\
\hline Housing & 6 & -2.30 & Housing & 2 & $-12.19^{*}(p$-value 0.00) \\
\hline Commercial & 2 & -3.71 & Commercial & 5 & $-13.44^{*}(p$-value 0.00) \\
\hline Policy & 5 & -2.70 & Policy & 4 & $-7.60^{*}(p$-value 0.00) \\
\hline
\end{tabular}

Note: * denotes the rejection of null hypothesis at $1 \%$ siginificance level. Bandwidths are chosen according to Newey-West using Bartlett kernel. Critical values are from McKinnon (1996).

As it can be seen from Table 2, existence of unit root cannot be rejected for all series however, when first differences of the series are taken, the null hypothesis can be rejected at $1 \%$ significance level pointing to stationarity.

Results of KPSS test in Table 3 show that the nul hypothesis of stationarity is rejected at $1 \%$ significance level for all series. However, stationarity hypothesis cannot be rejected for the first differences of all series. As a result, all three unit root tests indicate that the series under consideration are stationary after taking first difference indicating that all are I(1). 
Table 3. KPSS unit root test results for all series

\begin{tabular}{lccccc}
\hline \multicolumn{1}{c}{ Kevel } & Bandwidth & $\begin{array}{c}\text { Trend } \\
\text { and Intercept }\end{array}$ & $\begin{array}{c}\text { First } \\
\text { difference }\end{array}$ & Bandwidth & $\begin{array}{c}\text { Trend } \\
\text { and Intercept }\end{array}$ \\
\hline Cash & 8 & $0.27^{*}(p$-value 0.00) & Cash & 5 & 0.10 \\
\hline Vehicle & 8 & $0.27^{*}(p$-value 0.00) & Vehicle & 1 & 0.08 \\
\hline Housing & 8 & $0.26^{*}(p$-value 0.00) & Housing & 14 & 0.09 \\
\hline Commercial & 8 & $0.26^{*}(p$-value 0.00) & Commercial & 0 & 0.10 \\
\hline Policy & 9 & $0.23^{*}(p$-value 0.00) & Policy & 5 & 0.17 \\
\hline
\end{tabular}

Note: ${ }^{*}$ denotes the rejection of null hypothesis at $1 \%$ siginificance level. Bandwidths are chosen according to Newey-West using Bartlett kernel. Critical values are from Kwiatkowski et al. (1992).

\subsection{TAR model}

In order to examine the interest rate pass-through mechanism in Turkey, we first regressed each banking retail rate on the policy rate separately and then modeled residuals according to TAR specification explained above. The results of cointegration test and symmetric adjustment test are shown in Table 4 below.

Table 4. Tests of cointegration and symmetric adjustment according to TAR model $(\tau=0)$

\begin{tabular}{lccccl}
\hline & $\rho_{1}$ & $\rho_{2}$ & $\rho_{1}=\rho_{2}=0$ & $\rho_{1}=\rho_{2}$ & \multicolumn{1}{c}{ Conclusion } \\
\hline Cash and policy & $\begin{array}{c}-0.30 \\
(-3.38)\end{array}$ & $\begin{array}{c}-0.23^{* *} \\
(-2.44)\end{array}$ & $8.70^{*}$ & $\begin{array}{c}0.25 \\
(0.62)\end{array}$ & $\begin{array}{l}\text { Cointegration exists } \\
\text { Symmetric adjustment }\end{array}$ \\
\hline Vehicle and policy & $\begin{array}{l}-0.30^{*} \\
(-3.19)\end{array}$ & $\begin{array}{c}-0.36 \\
(-3.72)\end{array}$ & $11.99 *$ & $\begin{array}{c}0.21 \\
(0.65)\end{array}$ & $\begin{array}{l}\text { Cointegration exists } \\
\text { Symmetric adjustment }\end{array}$ \\
\hline Housing and policy & $\begin{array}{l}-0.27 * \\
(-3.09)\end{array}$ & $\begin{array}{c}-0.68 \\
(-9.03)\end{array}$ & $45.54^{*}$ & $12.96 *$ & Cointegration exists \\
\hline Commercial and policy & $\begin{array}{l}-0.34 * \\
(-3.38)\end{array}$ & $\begin{array}{c}-0.44 \\
(-4.12)\end{array}$ & $14.19 *$ & $\begin{array}{c}0.56 \\
(0.46)\end{array}$ & $\begin{array}{l}\text { Cointegration exists } \\
\text { Symmetric adjustment }\end{array}$ \\
\hline
\end{tabular}

Note: $*$ indicates significance at $1 \%$.

In Table 4, the second and the third columns show the values of adjustment parameters of $\rho_{1}$ and $\rho_{2}$ with their $t$ statistics in parenthesis. Larger of the $t$ statistics is compared with the critical values given in Table 2-Panel A of Enders and Siklos (2001) (-2.11 for $5 \%$ significance level and -2.55 for $1 \%$ significance level). The fourth column displays $F$ statistic for the null hypothesis of no cointegration $\left(\rho_{1}=\rho_{2}=0\right)$. The $F$ statistic is contrasted with the critical values given in Table 1-Panel A of Enders and Siklos (2001) (5.98 for 5\% significance level and 8.24 for $1 \%$ significance level). The fifth column shows the test results for the symmetric adjustment $\left(\rho_{1}=\rho_{2}\right)$ by stating the $F$ statistic with the correspondent probability in parenthesis. It is found that cointegration exists between the policy rate and the loan rates. Besides, positive discrepancies from the 
long run equilibrium adjust at the same speed with the negative discrepancies, leading to symmetric adjustment for the loan rates except housing rate. The $F$ statistic for the symmetric adjustment test indicates that there is an asymmetric adjustment between housing and policy rates.

As for the EC model, equation (5) is estimated for the loan rates for which cointegration with the policy rate is found. The following Table 5 presents the estimation results.

Table 5. Coefficients of EC models - TAR specification $(\tau=0)$

\begin{tabular}{|c|c|c|c|c|c|c|c|c|}
\hline & $\rho_{1}$ & $\rho_{2}$ & $\rho_{3}$ & $\rho_{4}$ & $\rho_{1}=\rho_{2}=0$ & $\rho_{1}=\rho_{2}$ & $\rho_{3}=\rho_{4}=0$ & Conclusion \\
\hline $\begin{array}{l}\text { Cash } \\
\text { and policy }\end{array}$ & $\begin{array}{l}-0.35^{*} \\
(-3.15)\end{array}$ & $\begin{array}{c}-0.20 * * \\
(-1.99)\end{array}$ & $\begin{array}{c}-0.12 \\
(-1.24)\end{array}$ & $\begin{array}{l}0.88 * \\
(4.41)\end{array}$ & $\begin{array}{c}6.85 \\
(0.00)\end{array}$ & $\begin{array}{c}0.99 \\
(0.32)\end{array}$ & $\begin{array}{l}11.71 \\
(0.00)\end{array}$ & $\begin{array}{l}\text { EC exists and } \\
\text { symmetric }\end{array}$ \\
\hline $\begin{array}{l}\text { Vehicle } \\
\text { and policy }\end{array}$ & $\begin{array}{c}-0.28 * * \\
(-2.19)\end{array}$ & $\begin{array}{l}-0.44^{*} \\
(-4.10)\end{array}$ & $\begin{array}{l}-0.07 \\
(-0.67)\end{array}$ & $\begin{array}{l}1.06^{*} \\
(4.28)\end{array}$ & $\begin{array}{l}10.98 \\
(0.00)\end{array}$ & $\begin{array}{c}0.93 \\
(0.34)\end{array}$ & $\begin{array}{l}13.42 \\
(0.00)\end{array}$ & $\begin{array}{l}\text { EC exists and } \\
\text { symmetric }\end{array}$ \\
\hline $\begin{array}{l}\text { Housing } \\
\text { and policy }\end{array}$ & $\begin{array}{l}-0.43^{*} \\
(-4.16)\end{array}$ & $\begin{array}{l}-0.33^{*} \\
(-2.87)\end{array}$ & $\begin{array}{c}0.08 \\
(1.13)\end{array}$ & $\begin{array}{l}0.50 * * \\
(2.53)\end{array}$ & $\begin{array}{l}12.94 \\
(0.00)\end{array}$ & $\begin{array}{c}0.36 \\
(0.55)\end{array}$ & $\begin{array}{c}7.13 \\
(0.00)\end{array}$ & $\begin{array}{l}\text { EC exists and } \\
\text { symmetric }\end{array}$ \\
\hline $\begin{array}{l}\text { Commer- } \\
\text { cial and } \\
\text { policy }\end{array}$ & $\begin{array}{l}-0.34^{*} \\
(-3.16)\end{array}$ & $\begin{array}{c}-0.23 * * \\
(-2.14)\end{array}$ & $\begin{array}{c}-0.17 \\
(-1.95)\end{array}$ & $\begin{array}{l}0.54 * \\
(3.62)\end{array}$ & $\begin{array}{c}7.17 \\
(0.00)\end{array}$ & $\begin{array}{c}0.54 \\
(0.46)\end{array}$ & $\begin{array}{c}6.72 \\
(0.00)\end{array}$ & $\begin{array}{l}\text { EC exists and } \\
\text { symmetric }\end{array}$ \\
\hline
\end{tabular}

Notes: $*$ indicates significance at $1 \%, * *$ indicates significance at $5 \%$.

Table 5 suggests that error correction is significant (the coefficients $\rho_{1}$ and $\rho_{2}$ ) revealing that there is long term relationship between loan rates and the policy rate. Also, positive and negative discrepancies from the long run path converge almost at the same speed to equilibrium. We cannot say that positive or negative departures from the equilibrium path are more persistent than the other. Pace of convergence is about 2-3 months for all loan rates. As for the individual significance of the parameters representing short run impact of the policy rate and the lag of retail rate, only the effect of policy rate is found to be statistically significant. However, column eight suggests that joint impact of the lag of loan rate and the policy rate on the retail loan rate is significant indicating the presence of short term relationship as well as the long term.

Our results are similar to the findings of Aydin (2007) and Ozdemir (2009) partially so that lending rates are sensitive to changes in monetary policy rate. The results of the TAR estimation showed that the interest rate pass-through from the policy rate to cash, vehicle, housing and commercial loan rates is significant and speed of convergence is almost a quarter. The adjustment processes for these loan rates are symmetric, too.

\subsection{MTAR model}

We performed the same analysis using the MTAR specification to see whether there is a difference, i.e. asymmetric behavior, between the expansionary and contractionary divergences of the series from their long run equilibriums. For this, we first replaced the indicator function $I$ with $M$ in equation (2) to analyze the cointegration relationship between the retail rates and the policy rate via MTAR model. 
Table 6. Tests of cointegration and symmetric adjustment according to MTAR model $(\tau=0)$

\begin{tabular}{lccccl}
\hline & $\rho_{1}$ & $\rho_{2}$ & $\rho_{1}=\rho_{2}=0$ & $\rho_{1}=\rho_{2}$ & \multicolumn{1}{c}{ Conclusion } \\
\hline Cash and policy & $\begin{array}{c}-0.26 \\
(-2.97)\end{array}$ & $\begin{array}{c}-0.29 * \\
(-2.96)\end{array}$ & $8.81^{*}$ & $\begin{array}{c}0.07 \\
(0.80)\end{array}$ & $\begin{array}{l}\text { Cointegration exists } \\
\text { Symmetric adjustment }\end{array}$ \\
\hline Vehicle and policy & $\begin{array}{l}-0.32^{*} \\
(-3.16)\end{array}$ & $\begin{array}{c}-0.30 \\
(-3.24)\end{array}$ & $10.24^{*}$ & $\begin{array}{c}0.02 \\
(0.88)\end{array}$ & $\begin{array}{l}\text { Cointegration exists } \\
\text { Symmetric adjustment }\end{array}$ \\
\hline Housing and policy & $\begin{array}{c}-0.31 \\
(-3.52)\end{array}$ & $\begin{array}{l}-0.28^{*} \\
(-2.64)\end{array}$ & $9.68^{*}$ & $\begin{array}{c}0.04 \\
(0.85)\end{array}$ & $\begin{array}{l}\text { Cointegration exists } \\
\text { Symmetric adjustment }\end{array}$ \\
\hline Commercial and policy & $\begin{array}{c}-0.16 \\
(-1.44)\end{array}$ & $\begin{array}{c}-0.43 \\
(-5.02)\end{array}$ & $13.62^{*}$ & $\begin{array}{c}3.77 \\
(0.06)\end{array}$ & $\begin{array}{l}\text { Cointegration exists } \\
\text { Symmetric adjustment }\end{array}$ \\
\hline
\end{tabular}

Notes: * indicates significance at $1 \%, * *$ indicates significance at $5 \%$.

Above Table 6 presents the test results of the cointegration relationship. Similar to the previous TAR analysis, the larger of the $t$ statistics given in parenthesis in the second and third columns is compared to the critical values given in Table 2-Panel B of Enders and Siklos (2001) (-2.02 for 5\% significance level and -2.47 for $1 \%$ significance level). The $F$ statistic in the fourth column is contrasted with the critical values presented in Table 1-Panel B of Enders and Siklos (2001) (6.51 for 5\% significance level and 8.78 for $1 \%$ significance level). Test of $t$ and $F$ statistics lead to rejection of no cointegration so that, there is a long term relationship between the policy rate and the loan rates. When we look at the adjustment speed of expansionary and contractionary movements to the equilibrium path, it can be said that recovery periods of positive and negative discrepancies are about the same except commercial rate. This indicates that, either positive or negative divergences are long-lasting over the other. The fifth column supports this claim with the test results of symmetric adjustment.

Next, the EC model with MTAR specification, which is given in equation (6), is estimated for cash, vehicle and housing loan rates. Table 7 below displays the results.

Table 7. Coefficients of EC models - MTAR specification $(\tau=0)$

\begin{tabular}{|c|c|c|c|c|c|c|c|c|}
\hline & $\rho_{1}$ & $\rho_{2}$ & $\rho_{3}$ & $\rho_{4}$ & $\rho_{1}=\rho_{2}=0$ & $\rho_{1}=\rho_{2}$ & $\rho_{3}=\rho_{4}=0$ & Conclusion \\
\hline $\begin{array}{l}\text { Cash and } \\
\text { policy }\end{array}$ & $\begin{array}{l}-0.26 * \\
(-2.61)\end{array}$ & $\begin{array}{l}-0.27 * \\
(-2.61)\end{array}$ & $\begin{array}{c}-0.13 \\
(-1.36)\end{array}$ & $\begin{array}{l}0.96^{*} \\
(5.07)\end{array}$ & $\begin{array}{c}6.29 \\
(0.00)\end{array}$ & $\begin{array}{c}0.00 \\
(0.97)\end{array}$ & $\begin{array}{l}15.99 \\
(0.00)\end{array}$ & $\begin{array}{l}\text { EC exists and } \\
\text { symmetric }\end{array}$ \\
\hline $\begin{array}{l}\text { Vehicle } \\
\text { and policy }\end{array}$ & $\begin{array}{l}-0.36^{*} \\
(-2.87)\end{array}$ & $\begin{array}{l}-0.39^{*} \\
(-3.78)\end{array}$ & $\begin{array}{c}0.06 \\
(-0.59)\end{array}$ & $\begin{array}{l}0.96^{*} \\
(4.16)\end{array}$ & $\begin{array}{l}10.45 \\
(0.00)\end{array}$ & $\begin{array}{c}0.05 \\
(0.82)\end{array}$ & $\begin{array}{l}13.62 \\
(0.00)\end{array}$ & $\begin{array}{l}\text { EC exists and } \\
\text { symmetric }\end{array}$ \\
\hline $\begin{array}{l}\text { Housing } \\
\text { and policy }\end{array}$ & $\begin{array}{l}-0.45^{*} \\
(-4.64)\end{array}$ & $\begin{array}{l}-0.30 * \\
(-2.80)\end{array}$ & $\begin{array}{c}0.08 \\
(1.15)\end{array}$ & $\begin{array}{l}0.51 * \\
(2.80)\end{array}$ & $\begin{array}{l}13.51 \\
(0.00)\end{array}$ & $\begin{array}{c}1.26 \\
(0.26)\end{array}$ & $\begin{array}{c}8.03 \\
(0.00)\end{array}$ & $\begin{array}{l}\text { EC exists and } \\
\text { symmetric }\end{array}$ \\
\hline $\begin{array}{l}\text { Commer- } \\
\text { cial and } \\
\text { policy }\end{array}$ & $\begin{array}{c}-0.29 * * \\
(-2.47)\end{array}$ & $\begin{array}{l}-0.29 * \\
(-3.07)\end{array}$ & $\begin{array}{l}-0.15 \\
(-1.81)\end{array}$ & $\begin{array}{l}0.57^{*} \\
(3.95)\end{array}$ & $\begin{array}{c}6.87 \\
(0.00)\end{array}$ & $\begin{array}{c}0.00 \\
(0.99)\end{array}$ & $\begin{array}{c}7.81 \\
(0.00)\end{array}$ & $\begin{array}{l}\text { EC exists and } \\
\text { symmetric }\end{array}$ \\
\hline
\end{tabular}

Notes: $*$ indicates significance at $1 \%, * *$ indicates significance at $5 \%$. 
Table 7 demonstrates that the estimation results of the MTAR model are similar to that of TAR model. There is a significant long run relationship between the policy rate and the loan rates under the MTAR model, too. Both positive and negative divergences from the equilibrium adjust to their long run trends at the same speed indicated by the test results of symmetric adjustment in the seventh column. In other words, contractionary movements are not faster or slower than expansionary movements while returning back to long term equilibrium path. The speed of adjustment is about 2-3 months. The short term effect of policy rate on the loan rates is high and significant for all loan rates. The significance of short term relationship between the loan rate, and its lag and the policy rate is also implied by the test results given in column eight.

The above results suggest that loan rates adjust to changes in policy rate faster than deposit rates. Besides, positive and negative shocks adjust symmetrically to long run equilibrium. Contrary to our analysis, Becker et al. (2010) found asymmetric adjustment of mortgage rates in the UK. Antao (2009) stated that deposit rates in Portuguese adjust faster than loan rates.

\subsection{Effects of financial crisis}

In order to see the impact of financial $\mathrm{crisis}^{3}$, a dummy variable is used for the period October 2008-September 2009, during which Turkey experienced negative growth rates, and the same analysis is repeated. However, the same results are observed at the end of this analysis. So, it can be said that financial crisis does not have significant impact over the long term course of interest rate pass-through in Turkey. The estimation results of financial crisis period are not given here to save space but they can be supplied from the authors upon request. However, Hansen and Welz (2011) reached a different conclusion for Sweden. They reported that although the pass-through from money market rates to retail rates was complete and sluggish before the crisis, it did not maintain for longer maturities after the crisis.

\section{Conclusion}

In this study, we examined the asymmetric adjustment properties of retail banking interest rates to changes in monetary policy rate in Turkey. Since monetary transmission mechanism is highly related to efficiency of the implementation of monetary policy, analysis of interest rate pass-through is important ${ }^{4}$. In fact, Kwapil and Scharler (2006) mentioned that the adjustment degree between the monetary policy rate and retail banking interest rates is important factor in determining the relationship between monetary policy actions and aggregate demand and inflation.

The empirical results of our analysis indicated statistically significant correlation between policy rate and cash, vehicle, housing and commercial loan rate. In other words, changes in the policy rate have significant influence on loan rates. As for the adjustment properties of discrepancies from the long term equilibrium, all retail banking rate series

\footnotetext{
${ }^{3}$ See Ucal et al. (2010).

${ }^{4}$ See Metin Ozcan et al. (2003).
} 
adjusted symmetrically to changes in policy rate. There is no asymmetry between positive and negative divergences in recovering to equilibrium path. The adjustment speed is about 2-3 months both for trough/peak and expansionary/contractionary movements. As for the monthly weighted average of 1-month, 3-month, 6-month and 12-month deposit rates, the same analysis was performed however, due to sluggish adjustment of deposit rates to policy rate, any significant cointegration relationship could not be reached for the deposit rates. Additionally, the speed and size of the pass-through do not show significant difference during the financial crisis. That is, symmetric adjustment property of loan rates to changes in policy rate is preserved during the financial crisis.

In order to make timely adjustments for policy rate and policy decisions, for easing liquidity in money market and for a smooth interest rate pass-through, central bank should take into account the adjustment speed of banking retail rates to changes in policy rate. The empirical results are consistent with the evidence so that, central bank fixes a short term policy rate according to a Taylor-type rule and conducts a short term monetary policy to keep actual interest rate fluctuations low and money market liquidity high. Short term effect of the policy rate on loan rates is found to be high and significant especially for cash and vehicle credit rates indicating that central bank has power over the loan rate market via changing the policy rate. Thus, impact of central bank decisions on inflation and output is considered to be high. On the other hand, in addition to monetary policy decisions, it should be noted that while setting the loan rates, banks take into account financial costs and risk premium, which depends on state of the economic environment.

In fact, our estimation results are particularly pertinent for banking sector dominated Turkish financial system. Besides, the relationship between aggregate demand and retail banking interest rates is important for an efficient monetary policy transmission mechanism and macroeconomic stability.

\section{References}

Agenor, P. R.; Alper, K. 2009. Monetary shocks and central bank liquidity with credit market imperfections, CBRT Research and Monetary Policy Department Working Paper No: 09/6.

Andion, C. L.; Sanfiz, J. M. M.; Penabad, M. C. L. 2010. Co-integration between mortgage markets in the monetary union: 1995-2008, Journal of Economics and Finance 60(1): 40-57.

Antao, P. 2009. The interest rate pass-through of the Portuguese banking system: characterization and determinants, Banco de Portugal Economics and Research Department Working Papers No: $5 / 2009$.

Aydin, H. I. 2007. Interest rate pass-through in Turkey, CBRT Research and Monetary Policy Department Working Paper No: 07/05.

Banking Regulation and Supervision Agency Press Release. 2012. Turkish Banking Sector NonConsolidated Main Indicators No: 2012/1. Ankara.

Becker, R.; Osborn, D. R.; Yildirim, D. 2010. A threshold cointegration analysis of interest rate pass-through to UK mortgage rates, Discussion Paper Series 141. Centre for Growth and Business Cycle Research, Economic Studies.

Bruna, K. 2008. Monetary policy stabilisation, changes in the banking system and interest rate pass-through: the Czech Republic 1999-2006, Post-Communist Economies 20(4): 413-429. http://dx.doi.org/10.1080/14631370802444575 
Chionis, D. P.; Leon, C. A. 2006. Interest rate transmission in Greece: did EMU cause a structural break?, Journal of Policy Modeling 28: 453-466. http://dx.doi.org/10.1016/j.jpolmod.2005.10.003

Cook, S. 2008. Econometric analysis of interest rate pass-through, Applied Financial Economics Letters 4: 249-251. http://dx.doi.org/10.1080/17446540701704372

De Bondt, G. 2005. Interest rate pass-through: empirical results for the euro area, German Economic Review 6: 37-78. http://dx.doi.org/10.1111/j.1465-6485.2005.00121.x

Dickey, D.; Fuller, W. 1979. Distribution of the estimators for autoregressive time series with a unit root, Journal of the American Statistical Association 74: 427-431.

Dickey, D.; Fuller, W. 1981. Likelihood ratio statistics for autoregressive time series with a unit root, Econometrica 49: 1057-1072. http://dx.doi.org/10.2307/1912517

Egert, B.; Crespo-Cuaresma, J.; Reininger, T. 2007. Interest rate pass-through in Dentral and Eastern Europe: reborn from ashes merely to pass away?, Journal of Policy Modeling 29: 209225. http://dx.doi.org/10.1016/j.jpolmod.2007.01.005

Enders,W.; Siklos, P. 2001. Cointegration and threshold adjustment, Journal of Business and Economic Statistics 19: 166-176. http://dx.doi.org/10.1198/073500101316970395

Fuertes, A. M.; Heffernan, S. A. 2009. Interest rate transmission in the UK: a comparative analysis across financial firms and products, International Journal of Finance \& Economics 14: 45-63. http://dx.doi.org/10.1002/ijfe.366

Gambacorta, L.; Iannotti, S. 2007. Are there asymmetries in the response of bank interest rates to monetary shocks?, Applied Economics 39: 2503-2517.

http://dx.doi.org/10.1080/00036840600707241

Gormez, Y. 2008. Banking in Turkey, Bank of Greece Working Paper No: 83.

Hansen, N. J. H.; Welz, P. 2011. Interest rate pass-through during the global financial crisis, OECD Economics Department Working Papers No: 855.

Haug, A. A.; Siklos, P. L. 2006. The behavior of short term interest rates: international evidence of non-linear adjustment, Studies in Nonlinear Dynamics \& Econometrics 10(4): 1-32.

http://dx.doi.org/10.2202/1558-3708.1276

Hofmann, B.; Mizen, P. 2004. Interest rate pass-through and monetary transmission: evidence from individual financial institutions' retail rates, Economica 71: 99-123.

http://dx.doi.org/10.1111/j.0013-0427.2004.00359.x

Humala, A. 2005. Interest rate pass-through and financial crises: do switching regimes matter? The case of Argentina, Applied Financial Economics 15: 77-94.

http://dx.doi.org/10.1080/0960310042000297908

Kara, H. 2006. Turkish experience with implicit inflation targeting, The Central Bank of the Republic of Turkey Working Paper No: 06/03.

Kleimeier, S.; Sander, H. 2006. Expected versus unexpected monetary policy impulses and interest rate pass-through in euro-zone retail banking markets, Journal of Banking \& Finance 30 : 1839-1870. http://dx.doi.org/10.1016/j.jbankfin.2005.07.006

Kwapil, C.; Scharler, J. 2006. Interest rate pass-through, monetary policy rules and macroeconomic stability, Oesterreichische Nationalbank Working Paper Series No: 118.

Kwiatowski, D.; Phillips, P. C. B.; Schmidt, P.; Shin, Y. 1992. Testing the null hypothesis of stationarity against the alternative of a unit root: how sure are we that economic time series have a unit root?, Journal of Econometrics 54: 159-178.

McKinnon, J. G. 1996. Numerical distribution functions for unit root and cointegration tests, Journal of Applied Econometrics 11: 601-618.

http://dx.doi.org/10.1002/(SICI)1099-1255(199611)11:6<601::AID-JAE417>3.0.CO;2-T 
Metin Özcan, K.; Gunay, A.; Ertac, S. 2003. Determinants of private savings behaviour in Turkey, Applied Economics 35: 1405-1416. http://dx.doi.org/10.1080/0003684032000100373

Ozdemir, B. K. 2009. Retail bank interest rate pass-through: the Turkish experience, International Research Journal of Finance and Economics 28: 7-15.

Panagopoulos, Y.; Reziti, I; Spiliotis, A. 2010. Monetary and banking policy transmission through interest rates: an empirical application to the USA, Canada, the UK and the Eurozone, International Review of Applied Economics 24(2): 119-136. http://dx.doi.org/10.1080/02692171003590096

Payne, J. E. 2006. The response of the conventional mortgage rate to the federal funds rate: symmetric or asymmetric adjustment?, Applied Financial Economics Letters 2: 279-284. http://dx.doi.org/10.1080/17446540600647037

Phillips, P. C. B.; Perron, P. 1988. Testing for unit roots in time series regression, Biometrika 75: 335-346. http://dx.doi.org/10.1093/biomet/75.2.335

Said, S. E.; Dickey, D. 1984. Testing for unit roots in autoregressive moving-average models with unknown order, Biometrika 71: 599-607. http://dx.doi.org/10.1093/biomet/71.3.599

Sander, H.; Kleimeier, S. 2004. Convergence in euro-zone retail banking? What interest rate pass-through tells us about monetary policy transmission, competition and integration, Journal of International Money and Finance 23: 461-492. http://dx.doi.org/10.1016/j.jimonfin.2004.02.001

Ucal, M.; Özcan, K. M.; Bilgin, M. H.; Mungo, J. 2010. Relationship between financial crisis and foreign direct investment in developing countries using semiparametric regression approach, Journal of Business Economics and Management 11(1): 20-33.

http://dx.doi.org/10.3846/jbem.2010.02

Tai, P. N.; Sek, S. K.; Har, W. M. 2012. Interest rate pass-through and monetary transmission in Asia, International Journal of Economics and Finance 4(2): 163-174.

http://dx.doi.org/10.5539/ijef.v4n2p163

The Banks Association of Turkey Statistical Reports. 2012. The Banking System in Turkey Quarterly Statistics by Banks, Branches and Employees December 2011 Report Code: DE13. Istanbul.

The Central Bank of the Republic of Turkey. 2007. Financial Stability Report No: 2. Ankara.

Wang, K. M.; Lee, Y. 2009. Market volatility and retail interest rate pass-through, Economic Modelling 26: 1270-1282. http://dx.doi.org/10.1016/j.econmod.2009.06.002

Wang, K. M.; Thi, T. B. N. 2010. Asymmetric pass-through and risk of interest rate: an empirical exploration of Taiwan and Hong Kong, Applied Economics 42: 659-670.

http://dx.doi.org/10.1080/00036840701704444

Ebru YÜKSEL is an Instructor at Department of Industrial Engineering at Hacettepe University, Ankara, Turkey. She received her PhD from Bilkent University. Her research interests are applied macroeconomics, time series analysis and finance. Her work has been published in Physica A and Applied Economics Letters.

Kivilcim Metin ÖZCAN is a Professor of Economics at Necmettin Erbakan University, Konya, Turkey. She received her PhD from the University of Oxford. Her research interests are macroeconomic modeling and time series analysis of aggregated macroeconomic and financial data. Her work has appeared in Oxford Bulletin of Economics and Statistics, Journal of Business and Economic Statistics, European Journal of Operational Research, Applied Economics, Applied Financial Economics, and Empirical Economics, Physica A, Emerging Market Finance and Trade. She is a fellow of Economic Research Forum at Cairo, Egypt and a Board member of Strategic Thinking Institute at Ankara, Turkey. 